\title{
Jessica Heesen \\ Universalisation, Totality and ICT, or: Are there any reasons for demanding ICT-free areas?
}

\begin{abstract}
:
In the following contribution we will investigate the digital divide with respect to a philosophically and ideologically founded concept of universalisation. The documents of the World Summit on the Information Society (WSIS) show that the creation of a global information society not only concerns a technical structural transformation, but also a technical implementation of a normative guiding principle. I will show that overcoming the digital divide corresponds to the inner logic of universalisation as an ethical model of reasoning. Furthermore, we will see that in reality this formal approach to reasoning proves to be a means of realising certain ideological perspectives. This interdependency of cultural dispositions and technical developments in the global information society will be shown in five aspects:

- The creation of a global social utopia based on the concept of the information society.

- The objectification of the concept of universalisation in information and communication technology (ICT).

- The linking of global internet use to a normative idea of the public sphere.

- The tendency towards totality as a problem of the public sphere and ICT.

- Possible reasons for demanding ICT-free areas.
\end{abstract}

\section{Agenda}

Information Technology as a defining technology

The information society as a social utopia

The Objectification of Universalism

Totality as a Problem of Public Sphere, or: The Trojan Horse

Totality as a Problem of ICT

Are there any reasons for demanding ICT-Free Areas?

\section{Author:}

J essica Heesen, M.A.:

- Universität Stuttgart, Abteilung für Wissenschaftstheorie und Technikphilosophie, Sonderforschungsbereich der Deutschen Forschungsgemeinschaft Nr. 627 "Nexus": Umgebungsmodelle für mobile kontextbezogene Systeme.

- $\triangle$ jessica.heesen@philo.uni-stuttgart.de, $\square$ www.uni-stuttgart.de/wt, www.nexus.uni-stuttgart.de

- Relevant publications:

- Orte des Dialogs: in den Massenmedien, im Internet und in einer „intelligenten“ Umgebung. Schwerpunkt: Dialog als Schlüsselbegriff medialer Kommunikation Forum Medienethik 2/ 2003, 32 - 41. In abgewandelter Form im Internet unter: Trans. Internet-Zeitschrift für Kulturwissenschaften 15/ 2004 (inst.at/trans/15Nr/inhalt15.htm), Schwerpunktheft: INST (Hg.): Das Verbindende der Kulturen.

- Ethik und Ethos der privaten Homepage, in: Thomas Hausmanninger (Hg.): Handeln im Netz. Bereichsethik und J ugendschutz im Internet (Schriftenreihe des ICIE Bd. 2), München: Fink 2003, $131-150$. 
- Medienethik, in: Marcus Düwell/ Christoph Hübenthal/ Micha H. Werner (Hg.): Handbuch Ethik. Stuttgart: Metzer 2002, 263 - 268.

- Individuelle Freiheitsrechte als Grundlage einer Ethik des Internet, in: Thomas Hausmanninger/ Rafael Capurro (Hg.): Netzethik. Grundlegungsfragen der Internetethik (Schriftenreihe des ICIE Bd. 1), München: Fink 2002, 163 - 180.

- Medienrealitäten - Ansätze der Ethik, Ethik und Unterricht 2/ 2002, 20 - 23. 


\section{Information Technology as a defining technology}

The term "information society" is one of the most prominent guiding principles at the start of the new millennium. It is associated with innovation, knowledge, mobility, transparency, participation, globalisation, or the New Economy. The broad thematic spectrum points to the high degree of penetration of new technology in society. ICT is not only a new technical application, but it is also a medium of a Weltanschauung.

Communication technologies have a far-reaching influence not only due to their geographical diffusion, but also because they have a mediative function in public spheres of society (societal reflection) and in contexts of every-day life such as the professional or family sphere (individual reflection) where they shape verbal communication as means of expression and reflection.

The vision of an information society relates to a comprehensive and fundamental system of values. Information technology can be labelled a "defining technology" (J. D. Bolter):

"A defining technology develops links, metaphorical or otherwise, with a culture's science, philosophy, or literature; it is always available to serve as a metaphor, example, model, or symbol. A defining technology resembles a magnifying glass, which collects and focuses seemingly disparate ideas in a culture into one bright, sometimes piercing ray. Technology does not call forth major cultural changes by itself, but it does bring ideas into a new focus by explaining or exemplifying them in new ways to larger audiences. "

Various research streams investigate the relationship between media technology and cultural form ( $R$. Debray, V. Flusser, P. Bourdieu) or the interdependency between the history of culture and the history of technology. Constructivism underlined the relevance of media for the organisation of social reality and the important role media plays in the formation of individual consciousness. Constructivist theories emphasise the participation of media on the emergence of the non-intentional structures of reality.

Constructivist theories of media as well as the above mentioned theories on the relationship between media technology and culture tend to supersede an empirical concept of media in favor of an epistemological concept. All positions, however, stress the close interdependency of technical developments and dominating social values, forms of experience and forms of organisation. Media technologies, just like technology in general, make certain paths accessible to exploring the human environment. They determine how we have to discern objective and social reality. From an epistemological perspective, these technologies are "filters" between us and the environment we can experience.

\section{The information society as a social utopia}

One of the aims of WSIS is to provide answers to the requirements of the new millennium. "To help all people to communicate" indicated Kofi Annan iii as one of the great millennium developing goals. The success of the information society depends on its ability to realize the equal participation of all nations. This is one of the fundamental differences between the information and the industrial society because the latter is functionally-based on the worldwide inequality in economic and societal development. For example, "leap-frogging" is mentioned in this connection to characterize that now, all societies can start from the infrastructural and technical level of industrial countries without making the same mistakes or going through timeconsuming development processes. ${ }^{\text {iv }}$

Hence, the information society is seemingly a comprehensive project that, similar to the great guiding principles "sustainability" or "justice" achieve their moral legitimation through the general participation and the uncoerced agreement of all who are affected by the effects of these goals. It is a concept of high normative imprinting, i.e. it contains strong normative claims.

"Our challenge is to harness the potential of information and communication technology to promote the development goals of the Millennium Declaration, namely the eradication of extreme poverty and hunger; achievement of universal primary education; promotion of gender equality and empowerment of women; reduction of child mortality; improvement of maternal health; to combat HIVIAIDS, malaria and other diseases; ensuring environmental sustainability; and development of global partnerships for development for the attainment of a more peaceful, just and prosperous world. 
We also reiterate our commitment to the achievement of sustainable development and agreed development goals, ...'

However, if the inner relationship between this social utopia and the so-called new digital media is considered as such, this relationship does not seem to be very strong. The establishment of air transport (accessibility), of cinema (information and clearness) or of telephone (communication) could, as a consequence, have had similarly euphoric visions. What is the reason for the "ethical overloading" of information technology?

\section{The Objectification of Universalism}

The reason for the overloading of information technology with moral expectations lies in the affinity to a certain tradition of thinking: ICT is the technical counterpart to universalisation as a historically intellectual basis of enlightenment. The era of enlightenment enforced the basic principle of universalism. Methodological generality of knowledge in natural sciences was groundbreaking for technical and medical progress. In the range of ethics, the procedure of universalisability guaranteed the impartiality of judgement and therewith the justness of an activity (I. Kant). The universalistic claims of the enlightenment are politically reflected in the justifying of democratic polity. In the 20th century the idea of universalisation became particularly relevant in relation to the normative dimension of discourse. In this context, universalisation is the characteristic of a specific discourse rationality (K.-O. Apel, J. Habermas). So far, Universalism can be characterised as the "meta-narrative" of the enlightenment (Lyotard).

The link between the concept of universalism and the democratic principles of "general participation" and "deliberation and discourse" lead us to a normative concept of the public sphere. It describes the function of the public sphere to criticise state and government through institutionally and judicially guaranteed possibilities of control. Even if this idea of public sphere is constructed in an ethically and religiously indifferent way, it is de facto connected to the social model of the western style liberal democracy respectively the highly developed industrialized countries. ${ }^{\mathrm{vi}}$ Such a concept of public sphere, that links the structural order of societal communication with particular ethical and ideological standpoints, is the basis of the ideas of the United Nations to bridge the digital divide.

For the first time in history, the new information technologies and the internet offer the possibility to realise a generally open interactive communication that is not reduced to individual communication. It supports a sort of communication that indicates the typical characteristics for the public sphere. Because of the interactive and theoretically unrestricted access to the internet it could be used for democratic and discursive processes. At the same time, it is a globally expanded network that some consider to be a suitable medium to build up a global public sphere ( $\mathrm{H}$. Rheingold, $\mathrm{O}$. Höffe). In the vision of a free information society, everyone is able and allowed to express any opinion. To express this in a more exaggerated way, we could say that the principle of universalisation is practically realised or objectified here. Furthermore one could say that in the information society the principle of universalisation is augmented from a counterfactual level (making decisions as if everyone could agree) to a quasi-factual level (factual possibility to agree).

Because the idea of universalism emerges from a model of justification and reasoning that is grounded in the ability for consensus of an imagined general public the conservation of the digital divide would be a performative contradiction: "The Information Society is intrinsically global in nature ..."vii The Information Society has to include everyone to prove itself at its own principles. Thus, bridging the digital divide complies with the already known notion of establishing a universal service to build up a critical Public Sphere within nations connected to ICT services. When we talk about the globalisation of the information society, it is a matter of the installation of a normative guiding principle that occurs in the shape of a technical innovation.

The term information society has the status of a regulative idea. It is the fictional centre of activities to reshape the real contexts, in other words the environment. "The information society creates an environment where all national sovereignties, religious, cultural, social and linguistic interests without any discrimination are respected and protected." The "Environment" is the intrinsic heart of the information society. The information society is not a material environment and not an actual form of society, but a principle of organisation with normative implications. The information society is a technically metaphorised meta-society. It is a dematerialised form of society, like the visions of 
cyber space existing without national territories and social contexts.

\section{Totality as a Problem of Public Sphere, or: The Trojan Horse}

The generalisation of the model of western society has obvious but also invisible cultural, societal and intellectual implications. For this, Michel Foucaults coined the term: microphysics of power.

Foucault is one of the critics of the idea of regulating of the public sphere. He connects the public discourse to an analysis of power relationships. Foucault argues that discourses are not guided rationally but through a power struggle. As a result there is no rational legitimation of the results of public discourse. viii Like another critic of the public sphere, Reinhart Koselleck, he points out the problem of totality. The normative authority of the public sphere enables the penetration of ideological components into the private sector. Koselleck maintains that sovereignty is not controlled and produced but mediated and masked by the public sphere. ${ }^{i x}$ According to this, the public sphere is based on a totalising discourse.

Without criticising the critics of a discursive type of democracy here we can state that in connection with the guiding principle information society, the expansion of the western horizon is accomplished with reference to humanistic visions, which no one, who wants to participate on the global communication-community, can reject. The "price" is a change of circumstances caused by technology. "We are indeed in the midst of a revolution, perhaps the greatest that humanity has ever experienced" (ITU, Basic Information) ${ }^{x}$.

An example of cultural change is an alienation from common traditions provoked by ICT. The WSIS Declaration underlines the protection of cultural diversity:

"The creation, dissemination and preservation of content in diverse languages and formats must be accorded high priority in building an inclusive Information Society, paying particular attention to the diversity of supply of creative work and due recognition of the rights of authors and artists.

[...] The preservation of cultural heritage is a crucial component of identity and selfunderstanding of individuals that links a community to its past. The Information Society should harness and preserve cultural heritage for the future by all appropriate methods, including digitisation" ${ }^{\prime \prime}$

The infiltration of various ICT applications in all cultural and societal spheres can help to save, archive and transfer traditional particularities of a community or nation. But moreover, it has the effect of alienation in respect of a practice previously integrated into everyday life. The assortment, systematisation and designation of heretofore disparate phenomena make them available for media-usage and open them to a broad audience. At the same time, this process provokes the aesthetification of the content and thus its objectification. At this level the content is much more readily disposed to criticism and reflection. An additional contribution to this de-contextualisation of a particular social and cultural context is given with the indispensable canonisation of its pluralistic form of appearance. Because of ICT-formatting, tradition can easily become folklore.

As a result on a normative level a process starts to work, which communitarians describe as alienation from common values. Here communitarians identify the reason for the transformation from pluralistic common tradition to abstract and unified legal systems.

For the strategy to provoke a cultural change beyond the facade of a helpful technology one can use the metaphor "Trojan Horse", even if I don't want to deny the willingness and results of many activists in overcoming the digital divide. After all, it becomes clear that the information society is not a matter of bridging the digital divide but about the trial to found a more just social order within a particular cultural and political paradigm.

\section{Totality as a Problem of ICT}

The internet, but also new developments in the field of ICT like the so called Ubiquitous Computing, stand for an individualised use of media. Another typical characteristic of ICT in the future is its omnipresence. For example, Ubiquitous Computing (also called Pervasive Computing or Ambient Intelligence) expands the electronic communication networks into the objective environment. The idea is to connect local networks and the World Wide Web with intelligent objects of utility. A ubiquitous ICT should disburden the human being while assisting in his or her activities in a unobtrusive and invisible 
way. The creation of a reliable infrastructure for everyday life should be guaranteed through wearables and robotics in the area of hardware and moreover by building up a "virtual space for matching people" ${ }^{u x i i}$, a kind of personalised world of electronic interaction. xiii

In spite of this increasing presence of a technical system in everyday life, the individual ${ }^{\text {xiv }}$ with his or her personal needs and preferences is at the centre of new ICT applications, particularly in the area of network technologies. Following the visions of software developers, autonomy and individuality should be conserved even if the user is involved in an all-embracing technical system. Scenarios of the future development of ICT show subjects in a constitutive way as parts of social networks. "Maintaining existing relationships and creating new ones is an essential feature of human life. "xv With this anthropological assumption, software developers argue similarly to the critics of subjectivity and post-modern concepts, who particularly stress the permeability of human identity for determinants from outside.

But how can this favourable image of individuality be realised if ICT and normatively imprinted concepts of a public sphere raise suspicion due to a tendency towards totalitarianism? In other words, how are liberal societies able to meet their claim to guarantee pluralism and self-realisation?

\section{Are there any reasons for demanding ICT-Free Areas?}

To raise the issue of the relationship between human beings and an intelligent or networked environment from an aesthetic point of view could be a contribution to answer this question.

If a society connects the constitution of individuality and personality with social relationships and worlds of experience from outside, it is confronted with the task of creating this "outside" in a diverse manner. Only by coping with this task can the individual capacity of autonomous and spontaneous reflection, radical critique and the new-thinking of habitual types of reflection in an enduring way be assured. Even in an ICT world centred on individuals we can find the unknown and unavailable only outside of data networks.

Resources of individuality are not only situated in the subject itself, but also in the freedom to choose a space of experience that is not restructured by
ICT. A setting free of ICT offers different aesthetic qualities $^{\mathrm{xvi}}$ to an environment that is integrated into data networks.

Many aesthetic theories deal with the impact of the external environment on the constitution of human beings as being one of sensual-bodily existence. ${ }^{\text {xvii }}$

In the context of Gernot Böhme's concept of an aesthetic of nature for example he points out the dependence of human dispositon on aesthetic values. ${ }^{\text {xiii }}$ It can be assumed that we consider an environment pervaded by computers in a different way to one not touched by ICT regardless of whether the setting is urban or rural.

We can speak about different qualities of impression $^{\text {xix }}$ in a networked environment on the one hand and a setting free of ICT and free of an independent "intelligence" on the other hand. Qualities of an ICT-free area are its insularity, its limitation on the local situation and its particular charisma. A networked world stresses its usability, ${ }^{x x}$ interaction and participaton in public communication. The negation of ICT applications promises the absence of control through a "big brother technology“, the absence of a public sphere and of a system of organisation according to an instrumental rationality as well as the avoidance of being addressed by an omnipresent digital network. Parallel to certain forms of argument of aesthetic theory referring to experience of nature, an ICT-free environment could mediate values like spontanity, autonomy and end in itself. Here, freedom shall be understood as an alternative to a ubiquous organisation and communication according to the principles of ICT.

The question is whether a technology with such a great influence on human experience and selfperception should be allowed to diffuse into all spheres of society and into all geographical areas. Why shouldn't the experience of an ICT-free environment - similar to the experience of nature be a necessary component of a concept of the good life?

To eliminate usable and helpful ICT applications from our everyday environment seems to be illusionary and without basis. In any event we have seen that there are good reasons to build up single ICT-free zones as parts of urban or rural areas. In a future world of ambient intelligence and ubiquitous digital networks they could offer - similar to nature reserves areas in the context of industrialised landscapes - a different dimension of experience. ICT-free zones could aesthetically enrich (maybe 
with ethical implications) the experience of reality. Even if such "reserves" are not desirable or relevant for the majority of population, like the so-called high culture they could be a valuable contribution to plurality and to the diversity of human experience and, last but not least, to the support of individual identities.

\section{References}

Annan, Kofi A. (2003), Presse und Meinungsfreiheit gehören zusammen. Erklärung zum Weltfernmeldetag - 17. Mai, in: http://www.gipfelthemen.de/globalegemeinscha ft/uno infogesellsch/index.shtml

Böhme, Gernot: Für eine ökologische Naturästhetik. Frankfurt a. M.: Suhrkamp 1989.

Bolter, Jay David: Turing's man. Western Culture in the computer age, London: Duckworth, 1984.

Bundesministerium für Bildung und Forschung, futur: Der deutsche Forschungsdialog, Leitvision vernetzte Welt "Tina und ihr Butler": http://www. futur. de/de/6455 6559.htm

Dierkes, Meinolf/ Lutz Marz: Leitbildprägung und Leitbildgestaltung. Zum Beitrag der Technikgenese-Forschung für eine prospektive Technikfolgen-Regulierung, Veröffentlichungsreihe der Abteilung Organisation und Technikgenese des Forschungsschwerpunkts Technik-Arbeit-Umwelt des Wissenschaftszentrums Berlin für Sozialforschung (WZB), FS // 92-105, 1992.

Elsner, Monika u. a., Zur Kulturgeschichte der Medien, in: Klaus Merten/ Siegfried J. Schmidt/ Siegfried Weischenberg (Hg.): Die Wirklichkeit der Medien. Eine Einführung in die Kommunikationswissenschaft, Westdeutscher Verlag, 1994, 163 - 187.

European Commission, Information Society Technologies Advisory Group (ISTAG), ISTAG Scenarios for Ambient Intelligence in 2010: http://www. cordis/lu/ist/istag. htm

Foucault, Michel: Die Ordnung des Diskurses, mit einem Essay von Ralf Konersmann, Frankfurt a. M.: Fischer 1997.

G 8, Okinawa Charter on Global Information Society: http://www. dotforce.org/reports/it1.htm/

Hohendahl, Peter Uwe (Hg.) unter Mitarbeit von Russell A. Berman, Karen Kenkel und Arthur Strum: Öffentlichkeit. Geschichte eines kritischen Begriffs, Stuttgart/ Weimar: Metzler 2000.

ITU, Basic Information: About WSIS, in: http://www. itu. int/wsis/basic/about.htm/
Koselleck, Reinhart: Kritik und Krise. Eine Studie zur Pathogenese der bürgerlichen Welt, Freiburg/ München: Alber, second edition 1969.

Ott, Konrad: Ökologie und Ethik. Ein Versuch praktischer Philosophie, Tübingen: Attempto 1993.

UN,

Millennium

Goals:

http://www. un.org/millenniumgoals/

WSIS, Civil Society Declaration "Shaping Information Societies for Human Needs", in: http://www. itu.int/wsis/

WSIS, Declaration of Principles "Building the Information Society: a global challenge in the new Millennium": http://www.itu.int/wsis/

Proceedings of the symposium "Localizing the Internet. Ethical Issues in Intercultural Perspective" sponsored by Volkswagen*Stiftung*, 4-6 October 2004, Zentrum für Kunst und Medientechnologie (ZKM, Karlsruhe)

' Jay David Bolter (1984): Turing's man. Western Culture in the computer age, London: Duckworth, p. 11.

ii See, Monika Elsner u. a., Zur Kulturgeschichte der Medien, in: Klaus Merten/ Siegfried J. Schmidt/ Siegfried Weischenberg (Hg.): Die Wirklichkeit der Medien. Eine Einführung in die Kommunikationswissenschaft, Opladen 1994, pp, 163 - 187, pp. 163 f. .

iii Kofi A. Annan (2003): Presse und Meinungsfreiheit gehören zusammen. Erklärung zum Weltfernmeldetag - $17 . \quad M a i$, http://www.gipfelthemen.de/globalegemeinschaft/ uno_infogesellsch/index.shtml

iv See, G8, Okinawa Charter on Global Information Society, $\quad$ Parapgraph 12 http://www.dotforce.org/reports/it1.html

$\checkmark$ WSIS, Declaration of Principles, Paragraph 2, without accentuations.

vi See the debate between communitarians and liberals.

vii WSIS, Declaration, Paragraph 60.

viii „Die geringe Verschiebung, die hier für die Geschichte der Ideen vorgeschlagen wird und die darin besteht, daß man nicht Vorstellungen hinter den Diskursen behandelt, sondern Diskurse als geregelte und diskrete Serien von Ereignissen diese winzige Verschiebung ist vielleicht so etwas 
wie eine kleine (und widerwärtige) Maschinerie, welche es erlaubt, den Zufall, das Diskontinuierliche und Materialität in die Wurzel des Denkens einzulassen“ Michel Foucault: Die Ordnung des Diskurses. Mit einem Essay von Ralf Konersmann, Frankfurt a. M.: Fischer erweiterte Ausgabe 1997, p. 38.

ix See, Koselleck, Reinhart: Kritik und Krise. Eine Studie zur Pathogenese der bürgerlichen Welt, Freiburg/ München: Alber, second edition 1969, pp. $136 \mathrm{ff}$.

$x$ Information Technology Union (ITU), Basic Information: About WSIS, in: www.itu.int/wsis/basic/about.html.

${ }^{x i}$ WSIS, Declaration, Paragraph 53 und 54.

xii European Commission, Information Society Technologies Advisory Group (ISTAG), ISTAG Scenarios for Ambient Intelligence in 2010: www.cordis/lu/ist/istag.htm, p. 33.

xiii See, Futur-Leitvision, Leben in der vernetzten Welt: individuell und sicher. P. 3. See also, the "Global Brain Project", Los Alamos.

xiv See, Futur-Leitvision, Leben in der vernetzten Welt: individuell und sicher. P. 3.

xv ISTAG-Annex 2, p. 32.

xvi Gernot Böhme: Für eine ökologische Naturästhetik. Frankfurt a. M.: Suhrkamp 1989, p. 30. He used in this context the expression "Umgebungsqualitäten".

xvii In the past for example Friedrich Schiller, Über die ästhetische Erziehung des Menschen ..., I mmanuel Kant, Kritik der Urteilskraft, or Theodor W. Adorno in his aesthetic theory.

xviii See, Konrad Ott: Ökologie und Ethik. Ein Versuch praktischer Philosophie, Tübingen 1993, p. 140.

xix Ott: Ökologie und Ethik, p. 140.

$x x$ Friedrich Dessauer used the term Dienstwertcharakter. 